Ewa Kosior

\title{
SYTUACJA PRAWNA MALŻONKA KONSUMENTA W TOKU POSTĘPOWANIA UPADŁOŚCIOWEGO
}

\section{Wprowadzenie}

Instytucja upadłości i regulacje prawa upadłościowego znane są prawu polskiemu już od czasów międzywojennych. Jako pierwsze kompleksowo tematykę tę regulowało rozporządzenie Prezydenta RP z dnia 24 października 1934 r. Prawo upadłościowe ${ }^{1}$. Obecnie obowiązująca ustawa Prawo upadłościowe i naprawcze z dnia 28 lutego 2003 r. $^{2}$ zdecydowanie szerzej i szczegółowiej zajmuje się problemem i skutkami ogłoszenia upadłości. Ponadto, novum na gruncie prawa upadłościowego jest regulacja upadłości ogłaszanej w stosunku do osoby fizycznej nieprowadzącej działalności gospodarczej, czyli tzw. upadłości konsumenckiej.

Warto zwrócić uwagę na jeden z aspektów upadłości ogłaszanej w stosunku do osoby fizycznej nieprowadzącej działalności gospodarczej i skutki ogłoszenia upadłości konsumenckiej na majątkowe stosunki małżonków. W praktyce szczególnie ważne miejsce zajmuje problematyka uprawnień i ograniczeń, jakie w tym przedziale czasu odnoszą się do małżonka upadłego.

Ustrój majątkowy między małżonkami ma niewątpliwy wpływ na stosunki łączące małżonków z osobami trzecimi, które mają charakter stosunków „zewnętrznych" w odniesieniu do relacji majątkowych między małżonkami³.

Ustrój ustawowy pełni wśród ustrojów majątkowych szczególną rolę ze względu na fakt jego powstania z mocy samego prawa i, o ile nie zachodzą niżej powołane sytuacje, będzie ustrojem właściwym dla większości małżeństw. Zgodnie z art. $31 \S$ 1 k.r.o. $\mathrm{z}$ chwila zawarcia małżeństwa powstaje między małżonkami, z mocy ustawy, ustrój wspólności majątkowej. Zdarzeniem, będącym warunkiem sine qua non,

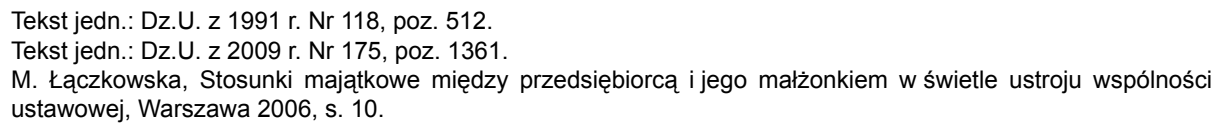


z którym ustawa łączy skutek w postaci powstania wspólności, jest zatem zawarcie związku małżeńskiego.

Wspólność majątkowa nie powstaje, jeżeli przyszli małżonkowie zawarli wcześniej małżeńską umowę majątkową. Ponadto, nie powstanie ona również, jeśli jeden z małżonków (lub oboje), zawierając związek małżeński, był ubezwłasnowolniony. Kolejną przesłanką uniemożliwiającą powstanie ustroju wspólności majątkowej jest uprzednie ogłoszenie upadłości w stosunku do jednego lub obojga małżonków. Za bezzasadne należy zatem uznać twierdzenia, iż jeśli małżonek i upadły, zawierając związek małżeński nie uregulują uprzednio w umowie ustroju majątkowego, powstanie między nimi wspólność majątkowa ${ }^{4}$. Przyjęcie rozwiązania, że w przypadku zawarcia małżeństwa z osobą, w stosunku do której ogłoszono upadłość, dojdzie do powstania ustroju wspólności, pozostawałoby w sprzeczności z uregulowaniami zawartymi w art. 124-126 p.u.n. i godziłoby także w interesy małżonka osoby, w stosunku do której została ogłoszona upadłośćs.

W zakresie ustroju ustawowej wspólności majątkowej funkcjonują trzy majątki: majątek wspólny i majątki osobiste małżonków. Do powołanych mas majątkowych zastosowanie znajdą przepisy art. 31 i nast. k.r.o. Należy jedynie przypomnieć, że majątek wspólny to masa majątkową, na którą składają się (lub mogą się składać) rozmaite prawa stanowiące przedmiot wspólnego prawa małżonków ${ }^{6}$. Wejście określonego przedmiotu majątkowego do majątku wspólnego małżonków nie zależy od sposobu, a jedynie chwili jego nabycia. Nie ma przy tym znaczenia, czy majątek został nabyty w drodze czynności prawnej, czynności faktycznej czy też innej czynności, z którą ustawa łączy skutek w postaci nabycia prawa. Podstawowym warunkiem wejścia określonego składnika do majątku wspólnego jest zatem nabycie go w czasie pozostawania w ustroju wspólności.

\section{Masa upadłości a majątek wspólny małżonków}

Szczegółowe kwestie dotyczące wpływu ogłoszenia upadłości na stosunki majątkowe małżonków regulują art. 124-126 p.u.n., które w przypadku upadłości konsumenckiej należy - zgodnie z art. 4912 p.u.n. - stosować odpowiednio. Zgodnie $\mathrm{z}$ art. $124 \S 1$ p.u.n. $\mathrm{z}$ dniem ogłoszenia upadłości jednego $\mathrm{z}$ małżonków powstaje między małżonkami rozdzielność majątkowa. O wpływie ogłoszenia upadłości na ustrój majątkowy małżonków stanowią również regulacje prawa rodzinnego. Zgod-

S. Gurgul, Prawo upadłościowe i naprawcze. Komentarz, Warszawa 2010, s. 447.

E. Skowrońska-Bocian, Rozliczenia majątkowe małżonków w stosunkach wzajemnych i wobec osób trzecich, Warszawa 2006, s. 29.

6

Ibidem, s. 28 
nie z art. $53 \S 1$ k.r.o., w razie ogłoszenia upadłości jednego z małżonków, powstaje z mocy prawa rozdzielność majątkowa.

Pod względem skuteczności omawiany ustrój rozdzielności przymusowej należy do kategorii ustrojów skutecznych erga omnes (zob. art. 435 § 1 kpc.). Odmianę ustroju małżonków, z których jeden ma status upadłego, charakteryzuje: rozdzielność, obligatoryjność, powszechna skuteczność oraz powstanie z mocy prawa z chwilą ogłoszenia upadłości. Jest to przy tym jedyny przymusowy ustrój majątkowy, który powstaje z chwilą ogłoszenia (a nie uprawomocnienia) postanowienia w przedmiocie upadłości. Zgodnie z art. $53 \S 2$ k.r.o. trwa on do czasu uchylenia, umorzenia lub ukończenia postępowania upadłościowego. Po zajściu jednego z przytoczonych zdarzeń prawnych ustrój przymusowy przekształca się w ustawowy ustrój majątkowy - ustrój wspólności. Warto podkreślić, iż ustrój ten powstaje niezależnie od tego, jaki uprzednio łączył małżonków ustrój majątkowy, tj. ustrój umowny czy ustawowy.

Zgodnie z art. 124 § 1 p.u.n., jeżeli małżonkowie pozostawali w ustroju wspólności majątkowej, majątek wspólny małżonków wchodzi do masy upadłości, a jego podział jest niedopuszczalny. Wynika to z art. 61 p.u.n., zgodnie z którym, z dniem ogłoszenia upadłości majątek upadłego staje się masą upadłości, która służy zaspokojeniu wierzycieli upadłego. Regulacja ta jest konsekwencją rozwiązań przyjętych w prawie materialnym, według których majątek wspólny małżonków ma służyć zaspokojeniu wierzycieli także wtedy, gdy dłużnikiem jest tylko jeden z małżonków ${ }^{7}$. Przy założeniu, że masa upadłości służy zaspokojeniu roszczeń wierzycieli, termin „majątek upadłego” należy rozumieć jako ogół aktywów przysługujących upadłemu, tj. wszelkie przedmioty stanowiące własność upadłego i wszelkie przysługujące mu prawa majątkowe ${ }^{8}$. W związku z powyższym, w skład masy upadłości wchodzi nie tylko majątek osobisty upadłego, ale również majątek wspólny małżonków. Ponadto w skład masy upadłości wchodzi cały majątek upadłego, należący do niego nie tylko w chwili ogłoszenia upadłości, ale również ten, który został nabyty w toku postępowania upadłościowego (art. 57 ust. 1, art. 61 i 62 p.u.n.).

Mimo że majątek wspólny wchodzi do masy upadłości, nie oznacza to, że w razie ogłoszenia upadłości małżonka wspólne mienie staje się własnością upadłego. Art. 124 p.u.n. trzeba oceniać wraz z art. 61 p.u.n., który mówi, że masę upadłości stanowi (z dniem ogłoszenia upadłości) majątek upadłego. W razie ogłoszenia upadłości wspólne mienie małżonków nie staje się własnością upadłego; wierzycieli można zaspokajać tylko z majątku upadłego ${ }^{9}$. Zaspokojenie wierzycieli powin-

\footnotetext{
7 Uzasadnienie do projektu ustawy Prawo upadłościowe i naprawcze z dnia 22 sierpnia 2008 r., druk sejmowy nr 809.

8 P. Janda, Wyłączenie z masy upadłości - podobieństwa i różnice nowego i starego prawa upadłościowego, „Prawo Spółek" 2003, nr 5, poz. 40.

$9 \quad$ Wyrok SN z dnia 30 października 2008 r., II CSK 242/08, LexPolonica nr 1959123.
} 
no zatem w ostatecznym rozrachunku nastąpić kosztem tej części majątku wspólnego, która po ustaniu wspólności przypadnie upadłemu. Mienie wchodzące do masy upadłości pozostaje składnikiem masy do czasu wyłączenia go spod reżimu prawa upadłościowego. Oznacza to, iż od inicjatywy współmałżonka upadłego zależy „uwolnienie” poszczególnych składników majątku wspólnego (wł. wierzytelności odpowiadającej udziałowi w majątku wspólnym). Ochrona małżonka upadłego dłużnika przejawia się bowiem w tym, że może on zgłosić do masy upadłości wierzytelność z tytułu udziału w majątku wspólnym (art. 124 ust. 3 p.u.n.). Skoro bowiem $\mathrm{z}$ chwilą ogłoszenia upadłości ustaje z mocy prawa wspólność majątkowa, a jednocześnie niedopuszczalny jest podział majątku wspólnego, to z tą datą powstaje roszczenie pieniężne o zaspokojenie wierzytelności z tytułu udziału w majątku wspólnym. Samo ustanie wspólności ustawowej nie powoduje bowiem „wyjścia" udziału małżonka upadłego z masy upadłości ${ }^{10}$.

\section{Wykonywanie zarządu a ogłoszenie upadłości}

Według art. $36 \S 2$ k.r.o. każdy z małżonków ma prawo do samodzielnego zarządu majątkiem wspólnym. Nie uchybia to obowiązkowi współdziałania w zarządzie majątkiem wspólnym, wynikającemu z art. $36 \S 1$ k.r.o. Małżonkowie mają również obowiązek informowania o zobowiązaniach obciążających majątek wspólny. Niewykonywanie tych obowiązków może jedynie skutkować ograniczeniem lub pozbawieniem prawa do samodzielnego zarządu majątkiem wspólnym (art. 40 k.r.o.) albo ustanowieniem przymusowej rozdzielności majątkowej (art. 52 k.r.o.), jako że obowiązek współdziałania w zarządzie dotyczy stosunków wewnętrznych między małżonkami ${ }^{11}$.

Złożenie wniosku o ogłoszenie upadłości nie ogranicza współmałżonka dłużnika w możliwości rozporządzania majątkiem wspólnym. Problematyczną może być kwestia dopuszczalności samodzielnego zgłoszenia wniosku o ogłoszenie upadłości konsumenckiej. Zgodnie z obowiązującą regulacją współmałżonek upadłego nie może skutecznie sprzeciwić się zgłoszeniu wniosku o ogłoszenie upadłości na podstawie art. 361 k.r.o. Lege non distunguente czynnościami zarządu są czynności cywilnoprawne, czynności procesowe oraz czynności faktyczne. Czynności cywilnoprawne i procesowe dotyczą przedmiotu majątkowego należącego do majątku wspólnego, gdy ich skutki prawne bezpośrednio odnoszą się do praw lub (posiadania) należących do majątku wspólnego. Za czynności zarządu uznaje się także takie, które dotyczą nie pojedynczego lub poszczególnych składników majątku, ale glo-

10 Zob. uzasadnienie wyroku SN z dnia 19 lutego 2009 r., II CSK 469/08, LEX nr 503240.

11 P. Wójcik, Zarząd majątkiem wspólnym małżonków, MoP 2006, nr 1, s. 29. 
balnie i bezpośrednio całego majątku ${ }^{12}$. Tym samym w kategorii czynności zarządu mieści się wniosek o ogłoszenie upadłości konsumenckiej, który z procesowego punktu widzenia jest czynnością dokonywaną samodzielnie przez dłużnika. Mając na uwadze powyższe, wniosek o ogłoszenie upadłości konsumenckiej nie jest wyłączony z zastosowania przepisu art. 361 k.r.o., ale sprzeciw mógłby być skuteczny jedynie wobec małżonka zamierzającego złożyć wniosek. Doktryna wskazuje bowiem na brak skutków procesowych zawiadomienia sądu o sprzeciwie skierowanym przeciw wnioskowi o ogłoszenie upadłości. W szczególności przepis art. 4913 p.u.n. nie wskazuje na sprzeciw jako na podstawę oddalenia wniosku o ogłoszenie upadłości ${ }^{13}$. Można jedynie zauważyć, że czynność taka co do zasady mieściłaby się zakresie czynności, które mogą być ważnie i skutecznie dokonane jedynie za zgodą współmałżonka (art. 37 k.r.o). Jej oprotestowanie rodzić by miało zatem sankcję bezskuteczności zawieszonej. Przyjęcie takiej koncepcji stałoby jednak z lex specialis prawa upadłościowego. Tym samym małżonek niewypłacalnego konsumenta postawiony został w bardzo niekorzystnej sytuacji, gdyż pozbawiono go możliwości wpływu na rozstrzygnięcie sądu w przedmiocie ogłoszenia upadłości swego współmałżonka.

Ogłoszenie upadłości dłużnika pozostającego w związku małżeńskim pociąga ten skutek, że z mocy prawa powstaje między małżonkami ustrój rozdzielności majątkowej oraz iż majątek wspólny małżonków wchodzi do masy upadłości. Powyższy skutek powstaje ipso iure. $\mathrm{Z}$ chwila ogłoszenia upadłości następuje zatem niemożność rozporządzania majątkiem wspólnym (sensu largo). W stosunku do dotychczasowego majątku upadły konsument zostaje całkowicie pozbawiony możliwości wykonywania uprawnień stanowiących podstawowe atrybuty prawa własności. Uprawnienia obejmujące władanie, korzystanie, zarządzanie i rozporządzanie majątkiem stanowiącym masę upadłości wykonuje syndyk pod nadzorem sędziegokomisarza (art. 75 ust. $1 \mathrm{w}$ zw. z art. 173 p.u.n.). Wyjątkowo tylko, za zezwoleniem sędziego-komisarza, upadły może prowadzić likwidację masy upadłości (art. 4911 ust. 5 p.u.n.). Może on jednak dokonywać czynności wyłącznie o charakterze rozporządzającym, nie zaś dotyczących władania i korzystania z majątku objętego masą upadłości ${ }^{14}$.

Analogiczne skutki ogłoszenia upadłości odnoszą się również do współmałżonka upadłego. Skoro majątek wspólny, zgodnie z regulacją art. 124 ust 1 p.u.n., wchodzi do masy upadłości, to prawo zarządu nad nim spoczywa na syndyku. W tej sytuacji zakaz zarządu oraz możliwości korzystania z mienia i rozporządzania nim przez upadłego, o którym mowa w art. 75 p.u.n., odnosi się również do współmał-

\footnotetext{
12 M. Nazar (w:) System Prawa Prywatnego. T. 11. Prawo rodzinne i opiekuńcze, pod red. T. Smyczyńskiego, Warszawa 2009, s. 324

13 Ibidem, s. 345

14 Za: S. Gurgul, Prawo upadłościowe..., s. 1267.
} 
żonka upadłego, mimo że ten przepis nie odnosi się wprost do niego ${ }^{15}$. Ogłoszenie upadłości dokonywane jest drogą konstytutywnego orzeczenia sądu - skutecznego i wykonalnego z chwila jego wydania (art. 52 p.u.n.). Dopiero takie postanowienie rodzi skutki cywilnoprawne oraz możliwość zastosowania art. 75 p.u.n. również w stosunku do współmałżonka.

W okresie pozostawania małżonków w ustroju wspólności majątkowej może dochodzić do konfliktów na tle zarządu majątkiem wspólnym małżonków. Skutkiem tego może być zainicjowanie postępowań sądowych w przedmiocie pozbawienia współmałżonka samodzielnego zarządu majątkiem wspólnym czy też udzielenia zezwolenia na dokonanie czynności przekraczających zakres zwykłego zarządu. Oznacza to, iż w przypadku ogłoszenia upadłości w wyżej powołanych sytuacjach toczące się postępowania winny zostać umorzone jako bezprzedmiotowe, a powództwa oddalone. $\mathrm{Z}$ chwilą ogłoszenia upadłości odpada bowiem istnienie merytorycznej przesłanki, jaką jest uprawnienie każdego ze współmałżonków do zarządu majątkiem wspólnym. Od momentu ogłoszenia upadłości zarząd majątkiem wspólnym - wchodzącym w skład masy upadłości - pozostaje bowiem w gestii syndyka. $\mathrm{Z}$ drugiej strony, uprzednie (względem ogłoszenia upadłości) orzeczenie zakazu zarządu majątkiem wspólnym w odniesieniu do upadłego małżonka nie może stanowić jakiejkolwiek podstawy ograniczenia czy wyłączenia majątku wspólnego z masy upadłości. Pozbawienie zarządu majątkiem wspólnym nie ma zatem wpływu na przysługujące małżonkom prawa rzeczowe, a jedynie na ich wykonywanie.

W przypadku ogłoszenia upadłości konsumenckiej między małżonkami powstaje rozdzielność majątkowa, a podział majątku wspólnego po ogłoszeniu upadłości jednego z małżonków jest niedopuszczalny. Tym samym małżonek upadłego, pomimo okoliczności, że pozostaje współwłaścicielem majątku wspólnego, nie może wykonywać uprawnień współwłaściciela przewidzianych przez przepisy prawa regulujące współwłasność w częściach ułamkowych. Uprawnienie do dokonania zniesienia współwłasności jest uprawnieniem niewykraczającym poza zakres czynności zwykłego zarządu. W przypadku ogłoszenia upadłości możemy mówić o swoistym pozbawieniu współmałżonka upadłego prawa podmiotowego wynikającego z bycia współwłaścicielem masy majątkowej, jako że możliwość wystąpienia z żądaniem zniesienia współwłasności jest uprawnieniem każdego ze współwłaścicie$1 i^{16}$. Również z tej okoliczności możemy wywieść, że współmałżonek upadłego, tracąc prawo swobodnego dysponowania majątkiem, traci również prawo zarządu.

Na podstawie art. 4912 ust. 5 sędzia-komisarz może zezwolić, żeby likwidację masy upadłości prowadził upadły pod nadzorem syndyka. Dopuszcza się zatem

\footnotetext{
15 Zob. uzasadnienie postanowienia SN z dnia 10 października 1995 r., II CRN 122/95, OSNC 1995, nr 12, poz. 186.

16 Za: M. Mosiołek, A.M. Redzimski, Wpływ ogłoszenia upadłości na stosunki majątkowe upadłego, Studencka Poradnia Prawna, nr 5, Białystok 2005, s. 142.
} 
stosowanie per analogiam art. 76 p.u.n., który w postępowaniu z możliwością zawarcia układu przewiduje powierzenie upadłemu zarządu własnego ${ }^{17}$. Sędzia-komisarz udziela powyższego zezwolenia na wniosek upadłego. Możliwość zastosowania analogii należy ograniczyć jedynie do badania przesłanek dopuszczalności ustanowienia takiego sposobu likwidacji. Podkreślić jednak wymaga, że upadły, dokonując likwidacji swego majątku, uzyskuje szerokie uprawnienia, które jednak są nie w pełni samodzielne, bo wykonywane pod nadzorem syndyka. Upadły dokonuje likwidacji masy upadłości przez sprzedaż nieruchomości i ruchomości, przez ściagnięcie wierzytelności od dłużników upadłego i wykonanie innych jego praw majątkowych wchodzących w skład masy upadłości albo ich zbycie (art. 311 p.u.n.) - po uzyskaniu akceptacji syndyka. Przyjęcie koncepcji ${ }^{18}$, iż art. 4912 ust. 5 p.u.n. stanowi lex specialis w odniesieniu do art. 75 ust. 1 p.u.n., oznaczałoby - na gruncie powyższych rozważań - że również współmałżonek upadłego odzyskałby prawo zarządu poszczególnymi składnikami majątku, które stanowią masę upadłości. Jak wskazałam, na gruncie art. 4912 ust. 5 p.u.n. upadły uzyskuje możliwość dokonywania czynności o charakterze rozporządzającym, nie zaś dotyczących władania i korzystania z majątku objętego masą upadłości. Uprawnienie to nabywa jedynie upadły, ale nie jego współmałżonek, który w dalszym ciagu pozbawiony jest prawa zarządu. Przyjęcie innej interpretacji mogłoby rodzić (w gruncie rzeczy bezzasadne) pytania o obowiązek uzyskania zgody na dokonanie poszczególnych czynności, które na gruncie prawa rodzinnego wymagają zgody współmałżonka (art. 37 k.r.o.). Przede wszystkim jednak taka interpretacja stwarzałaby małżonkowi upadłego możliwości korzystania z mienia i rozporządzania nim. W tym kontekście należy przypomnieć, iż przepisy ius cogens prawa upadłościowego wyłączają stosowanie regulacji prawa rodzinnego, a możliwość przywrócenia małżonkowi upadłego prawa zarządu i swobodnego dysponowania składnikami masy upadłości stawałaby w sprzeczności z istotą i zasadami postępowania upadłościowego prowadząc $a b$ absurdo.

Powyższe zasady, zgodnie z art. 124 ust. 5 p.u.n., nie dotyczą przedmiotów służących wyłącznie małżonkowi upadłego do prowadzenia działalności gospodarczej lub zawodowej, z wyjątkiem przedmiotów majątkowych nabytych do majątku wspólnego w ciągu dwóch lat przed dniem złożenia wniosku o ogłoszenie upadłości. Powyższe oznacza, iż przedmioty te nie wchodzą do masy upadłości, a więc nie istnieje jakiekolwiek ograniczenie w zakresie ich zarządu. Mimo że przedmioty te służą do prowadzenia działalności przez małżonka upadłego i zarządza on nimi samodzielnie, to i tak stanowią przedmiot wspólności majątkowej małżonków (wspólność ułamkowa powstała z przekształcenia wspólności łącznej). Stanowią zatem

\footnotetext{
17 A.J. Witosz, (w:) R. Adamus, A.J. Witosz, A. Witosz, Upadłość konsumencka. Komentarz praktyczny, Warszawa 2009, s. 41.

18 Ibidem, s. 46.
} 
majątek upadłego, który nie wchodzi do masy upadłości, a do którego znajdą zastosowanie art. 4915 oraz 124 ust. 5 p.u.n.

Jak wiadomo, jeżeli w skład majątku wspólnego małżonków wchodzi udział w spółce kapitałowej, to wejdzie on do masy upadłości. Przynależność udziału do majątku wspólnego nie oznacza wcale, że wspólnikami muszą być oboje małżonkowie. W spółkach kapitałowych o statusie wspólnika decyduje to, kto objął akcje (udziały), niezależnie od tego, skąd pochodziły środki na ich objęcie. Decydujące znaczenie ma zatem stwierdzenie, kto był stroną danej czynności prawnej ${ }^{19}$. Prawa i obowiązki wynikające z udziału (akcji) wykonuje zatem ten z małżonków, który był stroną czynności prawnej ${ }^{20}$. Jest on zatem - w stosunkach zewnętrznych - jedynym uprawionym do wykonywania zarządu tym szczególnym składnikiem majątku wspólnego. Taka okoliczność nie wpływa na ustalenie składu masy upadłości, czy też nie modyfikuje sposobu jej zarządu. Oznacza to, iż uprawnienia związane $\mathrm{z}$ uczestnictwem w spółce wykonywać będzie syndyk, zgodnie z art. 186 p.u.n. Nie ma przy tym znaczenia, o jakie uprawnienia chodzi. W hipotezie powołanego artykułu zawierają się zarówno uprawnienia organizacyjne (korporacyjne), jak i ściśle majątkowe. $\mathrm{W}$ konsekwencji, współmałżonek upadłego $\mathrm{w}$ toku postępowania - wraz z likwidacją tego składnika majątku - utraci status wspólnika spółki kapitałowej. Małżonek upadłego ponosi zatem negatywne konsekwencje ogłoszenia upadłości swego współmałżonka - traci on wszelkie uprawnienia związane z uczestnictwem w spółce. Należy jednak pamiętać, że dochodzi tu do rozdzielenia dwóch sfer - stosunków prawnorodzinnych i spółkowych, i dopiero całościowe spojrzenia na dane zagadnienia uzasadnia wkroczenie w uprawnienia spółkowe drugiego ze współmałżonków.

Zgodnie $\mathrm{z}$ art. 4918 p.u.n., z chwilą uprawomocnienia się postanowienia o ustaleniu planu spłaty wierzycieli powołanie syndyka wygasa z mocy prawa. Nie jest więc potrzebne w tym zakresie postanowienie sądu. Oznacza to, że z tą chwilą współmałżonkowie odzyskują uprawnienia władcze w stosunku do składników majątku, które nie zostały zlikwidowane w toku postępowania upadłościowego. Jednakże upadły konsument nie może dokonywać czynności prawnych przekraczających granice zwykłego zarządu (art. 4919 ust. 1 p.u.n.). W toku postępowania w przedmiocie upadłości konsumenckiej upadły odzyskuje zatem prawo zarządu nieco wcześniej niż w przypadku upadłości dotyczącej przedsiębiorcy (vide: art. 364 ust. 1 p.u.n.). Incydentalnie bowiem będzie miała miejsce sytuacja, gdy zaspokojenie wszystkich wierzycieli nastąpi już na skutek podziału masy upadłości.

\footnotetext{
19 Zob. np. wyrok SN z 21 stycznia 2009 r., II CSK 446/08, MoP 2009 nr 4 oraz wyrok SN z dnia 20 maja 1999 r. sygn. akt I CKN 1146/97, OSNC 1999, nr 12, poz. 209; inaczej J.P. Jaworski, Nowelizacja przepisów Kodeksu spółek handlowych o spółce z ograniczoną odpowiedzialnością, cz. I, MoP 2004, nr 9, s. 401 - który twierdził, że wspólnikami stają się oboje małżonkowie. 20 o możliwości przyznania uprawnień korporacyjnych małżonkowi niebędącemu stroną czynności prawnej vide:
A. Stępień, Akcje należące do majątku wspólnego małżonków, PPH 2006, nr 12, s. 43 .
} 
Plan spłaty nie jest jednak stałym i obligatoryjnym elementem konsumenckiego postępowania upadłościowego ${ }^{21}$, gdyż ustalany jest na wniosek upadłego konsumenta. Wydanie i uprawomocnienie się postanowienia o ustaleniu planu spłaty wierzycieli jest warunkiem sine qua non drugiego etapu postępowania upadłościowego, tj. etapu spłaty wierzycieli. Brak takiego wniosku powoduje, iż postępowanie utknie w martwym punkcie. Ustawa nie przewiduje skutków niezgłoszenia wniosku. Sięgnąwszy do przepisów postępowania cywilnego, można zastosować art. $177 \S 1$ pkt 6 kpc., zgodnie z którym sąd może zawiesić postępowanie z urzędu, jeśli na skutek niewykonania przez upadłego innych zarządzeń nie można sprawie nadać dalszego biegu. $\mathrm{Z}$ upływem roku od wydania takiego postanowienia sąd umorzy postępowanie, zgodnie $\mathrm{z}$ art. $182 \S 1 \mathrm{kpc}$. Jednakże w tym czasie powołanie syndyka pozostaje w mocy. Zasadnie zatem wskazuje się na ujawnianie w uzasadnieniu postanowienia ustalającego ostateczną wysokość wynagrodzenia syndyka faktu, czy i kiedy nastąpiło wygaśnięcie jego powołania ${ }^{22}$. Określenie ex post momentu wygaśnięcia powołania syndyka może bowiem mieć skutek w odniesieniu do czynności dokonanych przez upadłego w okresie zawieszenia postępowania.

Kolejnym, charakterystycznym etapem postępowania w przedmiocie upadłości konsumenckiej jest wykonanie przez upadłego obowiązków określonych w planie spłaty wierzycieli. W przypadku upadłości przedsiębiorców postępowanie kończy się bowiem właśnie na wykonaniu ostatecznego planu podziału masy upadłości (art. 368 ust. 1 p.u.n.). W postanowieniu o ustaleniu planu spłaty wierzycieli upadłego konsumenta sąd określa, w jakim czasie, nie dłuższym niż pięć lat, upadły jest obowiązany spłacać należności niezaspokojone na podstawie planu podziału (art. 4917 § 1 p.u.n.). W okresie tym pomiędzy małżonkami funkcjonuje reżim rozdzielności majątkowej i do czasu prawomocnego zakończenia postępowania upadłościowego nie może być - jako ustrój przymusowy - modyfikowany wolą stron.

\section{Wyłączenia z masy upadłości składników majątku osobistego}

Do masy upadłości nie będą wchodzić pewne składniki majątku wspólnego, podlegające wyłączeniu ustawowo, tj. na podstawie art. 63-67 p.u.n. Natomiast takie składniki mienia, które nie należą do majątku upadłego, podlegają wyłączeniu z masy upadłości - zgodnie z art. 70 p.u.n. W razie ogłoszenia upadłości pomiędzy małżonkami mogą zatem powstać spory co do tego, czy dany składnik majątku należy do majątku osobistego czy wspólnego. Przedmiotowy spór winien być rozstrzygany na płaszczyźnie art. 70 i nast. p.u.n. W omawianej sytuacji małżonek upadłego może zgłosić wszelkie twierdzenia, zarzuty i dowody na poparcie okoliczności,

21 R. Adamus, (w:) op. cit., s. 16.

22 S. Gurgul, Prawo upadłościowe..., s. 1277. 
iż dany składnik mienia nie stanowi majątku upadłego współmałżonka - czy to jako przedmiot należący do majątku osobistego, czy też majątku wspólnego małżonków. Stosowny wniosek rozpoznaje najpierw sędzia-komisarz (art. 73 ust. 2 p.u.n.). Jeżeli nie uwzględni on tego wniosku, małżonek dłużnika może złożyć stosowny pozew do sądu upadłościowego (art. 74 ust. 1 p.u.n.). Nie ma przy tym znaczenia, czy małżonek żąający wyłączenia z masy upadłości określonego składnika jest wyłącznie do niego uprawnionym. Prawo upadłościowe i naprawcze nie wymaga bowiem, aby przedmiot wyłączenia należał jedynie do wyłączającego, lecz tylko, aby nie należał do upadłego ${ }^{23}$.

W interesie małżonka upadłego pozostaje wyłączenie określonych składników z masy upadłości. Może to nastapić nie tylko na wniosek małżonka, ale również $\mathrm{z}$ inicjatywy syndyka. W sytuacji, gdy nastąpiło zbycie rzeczy ulegającej wyłączeniu, uzasadnione będzie roszczenie małżonka o tzw. wyłączenie zastępcze ${ }^{24}$. Podkreślenia wymaga stwierdzenie, iż w niniejszym postępowaniu można żądać jedynie wyłączenia poszczególnych przedmiotów (składników) majątkowych, a nie udziału w majątku wspólnym. Dla dochodzenia wierzytelności z tytułu udziału w majątku wspólnym przewidziana jest odrębna procedura.

Należy przy tym opowiedzieć się za poglądem, iż podstawą rozstrzygania sporów dotyczących przynależności określonego przedmiotu do majątku wspólnego lub osobistego nie może być art. 4915 p.u.n. Odnosi się on bowiem explicite do przedmiotów, które należą do upadłego ${ }^{25}$. W powołanym przepisie wątpliwość dotyczy zatem tego, czy dany składnik majątku, do którego upadły jest uprawniony, wchodzi do masy upadłości.

\section{Dochodzenie wierzytelności z tytułu udziału w majątku wspólnym}

Małżonek upadłego może dochodzić w postępowaniu upadłościowym należności z tytułu udziału w majątku wspólnym przez zgłoszenie wierzytelności sędziemu-komisarzowi. Sędzia-komisarz umieści tę wierzytelność na liście wierzytelności (art. 255 p.u.n.). Na marginesie warto zauważyć, iż umieszczenie należności z tytułu udziału w majątku wspólnym przez zgłoszenie jej sędziemu-komisarzowi obejmuje nie tylko wierzytelności powstałe bezpośrednio w związku z ogłoszeniem upadłości, ale również takie, które powstały na skutek ustania wspólności na podstawie innych zdarzeń prawnych. Chodzi tutaj o skuteczne względem masy upadłości orzeczenie separacji, ubezwłasnowolnienia czy ustanowienie rozdzielności majątkowej mocą umowy lub orzeczenia sądu (vide: art. 125 - 126 p.u.n.).

P. Janda, Status osoby trzeciej w postępowaniu upadłościowym, „Prawo Spółek” 2005, nr 3, s. 4.

Wyrok Sądu Apelacyjnego w Szczecinie z dnia 7 lutego 2008 r., I ACa 611/07, LEX nr 50325.

25 S. Gurgul, Prawo upadłościowe..., s. 1268. 
Udziały w majątku wspólnym małżonków są równe (art. $43 \S 1$ k.r.o.), wobec czego zgłoszona przez małżonka wierzytelność powinna odpowiadać połowie wartości majątku wspólnego według cen z daty ogłoszenia upadłości. Może to go uczynić głównym wierzycielem. Uzasadnione są zatem stwierdzenia, iż skorzystanie $\mathrm{z}$ tego prawa przez małżonka upadłego może w praktyce budzić wątpliwości co do możliwości realnego zaspokojenia innych wierzycieli ${ }^{26}$. Wierzytelność z tytułu udziału w majątku wspólnym ulegnie zaspokojeniu w kategorii czwartej (art. 342 ust. 1 pkt 4 p.u.n.).

Dopuszcza się możliwość zgłoszenia wierzytelności w wyższej wysokości - na podstawie art. $43 \S 2$ i 3 k.r.o. - jako rezultat ustalenia nierównych udziałów w majątku wspólnym ${ }^{27}$. Jeśli postępowanie w przedmiocie ustalenia nierównych udziałów nie uległo zakończeniu do czasu ogłoszenia upadłości, to ulegnie ono zawieszeniu na podstawie art. $174 \S 1$ ust. 4 kpc. Jeśli jednak już przed ogłoszeniem upadłości małżonkowie uzyskali prawomocny wyrok o ustaleniu nierównych udziałów, to ma on wiążące znaczenie w postępowaniu upadłościowym (o ile ustanie wspólności jest skuteczne względem masy upadłości - art. 125 - 126 p.u.n.).

Orzeczenie o ustaleniu nierównych udziałów odnosi skutek ex tunc, tzn. od chwili ustania wspólności majątkowej ${ }^{28}$. Konsekwencją wstecznego działania orzeczenia sądu o ustaleniu nierównych udziałów w majątku wspólnym jest bezskuteczność - względem jednego z małżonków - wcześniejszego zbycia przez drugiego z małżonków udziału w majątku wspólnym w części, która przewyższa wartość jego udziału ustaloną w orzeczeniu. Za bezskuteczną nie można jednak uznać czynności zbycia w postępowaniu upadłościowym przedmiotu dotychczas wchodzącego do majątku wspólnego. Po pierwsze, przepisy prawa upadłościowego stanowią lex specialis $\mathrm{w}$ stosunku do przepisów prawa rodzinnego, a zgodnie z nimi majątek wspólny w całości wchodzi do masy upadłości, nawet jeśli ustalenie nierównych udziałów doprowadziło do tego, że jeden z małżonków został całkowicie pozbawiony udziału w majątku wspólnym. Po drugie, zbycie przedmiotu następuje niezależnie od woli dokonania takiej czynności przez dłużnika (chociaż składając wniosek o ogłoszenie upadłości, godzi się on na takie jego konsekwencje).

Zainteresowanym w ustaleniu nierównych udziałów może być nie tylko małżonek, ale i wierzyciele upadłego. Zważywszy, iż nie tylko małżonek, ale i wierzyciel może doprowadzić do określenia nierównych udziałów w majątku wspólnym małżonków z uwzględnieniem stopnia, w którym każdy z małżonków przyczynił się do

26 Tak: M. Szakun, Do ogłoszenia upadłości konsumenckiej trzeba mieć majątek i dochody, „Gazeta Prawna” z 18 sierpnia 2009.

27 S. Gurgul, Upadłość a majątkowe stosunki małżonków, MoP 2005, nr 6, s. 284.

28 Zob. np. wyrok SN z dnia 10 listopada 1976 r., II CR 268/76, OSNC 1977, nr 10, poz.18, odmienne poglady, tj. o skutkach ex nunc orzeczenia o ustaleniu nierównych udziałów, zob. np. M. Sychowicz, (w:) H. Ciepła i in., Kodeks rodzinny i opiekuńczy, Warszawa 2009, s. 266. 
powstania majątku wspólnego ${ }^{29}$, należy dopuścić możliwość takiego ustalenia przez syndyka posiadającego legitymację procesową do wszczęcia postępowań dotyczących masy upadłości (art. 144 p.u.n.).

Jeżeli w trakcie postępowania upadłościowego żądanie ustalenia nierównych udziałów małżonków w majątku wspólnym nie zostanie uwzględnione czy nawet zgłoszone, kwestie z tym związane mogą stać się przedmiotem rozstrzygnięcia dopiero po zakończeniu postępowania upadłościowego, w procesie między małżonkami (art. 263 p.u.n.). Prawo żądania ustalenia nierównych udziałów nie jest roszczeniem majątkowym w rozumieniu art. $117 \mathrm{i}$ nast. kc. $\mathrm{i}$ choćby $\mathrm{z}$ tego powodu nie ulegnie ono przedawnieniu ${ }^{30}$.

\section{Uwagi końcowe}

$\mathrm{Na}$ tle postępowania upadłościowego w przedmiocie upadłości konsumenckiej czas jest determinantem wielu zachowań i sytuacji prawnych.

Po pierwsze, wiążące się z jego upływem przeobrażenia wymusiły wprowadzenie nowej instytucji prawa, jaką jest - wciąż mocno krytykowana - regulacja upadłości konsumenckiej. Po drugie, w czasie postępowania upadłościowego obowiązują szczegółowe regulacje dotyczące małżeńskich ustrojów majątkowych. Do chwili umorzenia, uchylenia lub ukończenia postępowania upadłościowego obowiązuje przymusowy ustrój majątkowy. Na tle istoty postępowania upadłościowego, jaką jest oddłużenie upadłego, zasadne jest bowiem utrzymanie ustroju rozdzielności majątkowej przez cały okres postępowania upadłościowego. Ponadto przepisy prawa upadłościowego wprowadzają ograniczenia uprawnień przysługujących współmałżonkowi upadłego w stosunku do majątku wspólnego. Po trzecie, postępowanie w przedmiocie upadłości konsumenckiej odnosi się do sytuacji prawno-ekonomicznej upadłego w przyszłości, a będącej konsekwencją zachowań z przeszłości. Istota postępowania upadłościowego sprowadza się do oddłużenia upadłego. Oddłużenie nie dotyczy odpowiedzialności majątkiem, jakim dłużnik dysponuje w chwili otwarcia postępowania upadłościowego, bowiem majątek ten nie może być przedmiotem oddłużenia. Oddłużenie może zatem odnosić się jedynie do przyszłego majątku dłużnika, a dotyczy długów, których spłata z wcześniej posiadanego majątku nie była możliwa.

W tym świetle warto zauważyć, że czas może równie dobrze być punktem odniesienia czy granicą dywagacji, jak też siłą napędową dla rozwoju lub powstania nowych instytucji prawa. 


\title{
THE LEGAL POSITION OF A SPOUSE OF A BANKRUPT CONSUMER DURING BANKRUPTCY PROCEEDING
}

\author{
SUMMARY
}

The article regards the position of a spouse of a bankrupt consumer during bankruptcy proceeding. The date of issuing a decision declaring bankruptcy is the date of bankruptcy. From this time matrimonial property regime converts into a compulsory system of separate estates in matrimony. The joint matrimonial estate shall be included in the bankruptcy estate. The rules of management of matrimonial estate are converted. From this moment the course of bankruptcy proceeding depends on the bankrupt spouse's activity. They can pursue amounts resulting from their share in the joint matrimonial estate, filing the claim with the judge - commissioner. They can also demand exemption from the bankrupt estate assets which do not belong to the bankrupt. Sometimes they do not have any impact on the activity of a bankrupt spouse, for example, they cannot resist the petition to declare bankruptcy. During bankruptcy proceeding a bankrupt spouse is limited in their rights which regard joint matrimonial estate. This situation lasts to the valid conclusion of bankruptcy proceeding. The article emphasizes different depiction of time in the aspect of bankruptcy law. On the one hand, time assigns limits of divagations. During bankruptcy proceeding special rules regarding compulsory matrimonial property regime are in force. On the other hand, time is an impulse of transformation of law and enforcement of new legal institutions such as, for example, an institution of consumer bankruptcy. 